\title{
Calcium : magnesium ratio affects environmental stress sensitivity in the serpentine-endemic Alyssum inflatum (Brassicaceae)
}

\author{
Rasoul Ghasemi ${ }^{\mathrm{A}, \mathrm{F}}$, Zohreh Zare Chavoshi ${ }^{\mathrm{B}}$, Robert S. Boyd ${ }^{\mathrm{C}}$ and Nishanta Rajakaruna $\mathrm{D}, \mathrm{E}$ \\ ADepartment of Biology, Payame Noor University, 19395-4697, Tehran, I.R. of Iran. \\ ${ }^{B}$ Department of Biology, Payame Noor University, 81395-671 Isfahan, I.R. of Iran. \\ ${ }^{C}$ Department of Biological Sciences, Auburn University, Auburn, AL 36849, USA. \\ ${ }^{D}$ College of the Atlantic, Bar Harbor, ME 04609, USA. \\ EUnit for Environmental Sciences and Management, North-West University, Potchefstroom, 2520, South Africa. \\ ${ }^{\mathrm{F}}$ Corresponding author. Email: rasoul.ghasemi@es.isfpnu.ac.ir
}

\begin{abstract}
Plants endemic to serpentine soils are adapted to harsh environmental conditions typical of those soils, particularly, low $(<1)$ calcium $(\mathrm{Ca})$ : magnesium $(\mathrm{Mg})$ ratios. We compared survival of two perennial Alyssum species native to Iran under experimental manipulations of $\mathrm{Ca}: \mathrm{Mg}$ ratio, including when $\mathrm{Ca}: \mathrm{Mg}$ ratio was varied under conditions of high ammonium concentration and heat stress. Alyssum inflatum is a serpentine endemic capable of nickel (Ni) hyperaccumulation, whereas A. lanceolatum is found on non-serpentine soils and is not known to hyperaccumulate Ni. We grew plants of both species under four $\mathrm{Ca}: \mathrm{Mg}$ ratios $(0.4,2,20,40)$ and tested survival when plants were exposed to elevated ammonium levels $(0,1$ and $4 \mathrm{mM})$ and heat stress (control conditions vs a 5-h $36 \mathrm{C}$ treatment daily for 5 days). Alyssum lanceolatum was more tolerant of $\mathrm{Ca}: \mathrm{Mg}$ ratio variation (100\% survival in all treatments), whereas $\mathrm{A}$. inflatum survival was maximum at $\mathrm{Ca}: \mathrm{Mg}=2$, reduced at $\mathrm{Ca}: \mathrm{Mg}=0.4$, and very low for $\mathrm{Ca}: \mathrm{Mg}$ ratios of 20 and 40 . Alyssum lanceolatum also tolerated ammonium and heat stress, whereas survival of $A$. inflatum declined at higher $\mathrm{Ca}: \mathrm{Mg}$ ratios when subjected to both stresses. We conclude that at higher $\mathrm{Ca}: \mathrm{Mg}$ ratios, the serpentine endemic has reduced tolerance for these environmental stresses and may be more susceptible to human-driven climate change-associated stressors than the non-serpentine species.
\end{abstract}

Additional keywords: global climate change, heat stress, local adaptation, nitrogen deposition, serpentine endemism.

\section{Introduction}

Soils are important habitats for many organisms; the physical and chemical properties of soils vary greatly and this variation can be an important factor that determines the distribution of species across the face of the planet (Rajakaruna and Boyd 2008). Serpentine soils are an excellent example of this principle (Harrison and Rajakaruna 2011). These soils develop from parent material generally classified as ultramafic rocks, having high concentrations of iron $(\mathrm{Fe})$ and magnesium $(\mathrm{Mg})$ and low concentrations of silicon ( $\mathrm{Si})$, and may contain elevated concentrations of some heavy metals such as cobalt (Co), chromium (Cr) or nickel (Ni) (Alexander et al. 2007). As a consequence of the chemistry of the parent rocks, serpentine soils possess a suite of characteristics (termed the serpentine syndrome; Kruckeberg 1984) that challenge the growth of many maladapted plant species. These features often include a low calcium $(\mathrm{Ca})$ : magnesium $(\mathrm{Mg})$ ratio, high levels of some heavy metals and, in Mediterranean regions, these soils are often comparatively shallow and stony and more likely to create drought stress (Brady et al. 2005; Kazakou et al. 2008). Tolerance of a low soil $\mathrm{Ca}: \mathrm{Mg}$ ratio is considered to be a significant feature of serpentine adaptation (Bradshaw 2005; Palm et al. 2012). However, how serpentine-adapted species tolerate low $\mathrm{Ca}: \mathrm{Mg}$ ratios is still not well understood (see O'Dell and Rajakaruna 2011), although it is clear that the low $\mathrm{Ca}: \mathrm{Mg}$ ratio severely limits the growth of plants not adapted to serpentine soil (Palm and Van Volkenburgh 2014).

The challenging environmental conditions of serpentine soils have promoted the evolution of ecotypes or species that possess adaptations to those conditions (Kay et al. 2011; O'Dell and Rajakaruna 2011). In fact, some species adapted to serpentine soils are sufficiently specialised so that they are endemic to them (Anacker 2011, 2014). Serpentine endemism may be an important facet contributing to global biodiversity; for example, in California (USA), a global biodiversity hotspot (Myers et al. 2000), there are 246 taxa from 103 genera and 41 families 
endemic to serpentine soils (Safford et al. 2005; Anacker et al. 2011). Many serpentine endemics are known from other locations as well (e.g. Brooks 1987; Rajakaruna et al. 2009; Van der Ent et al. 2014).

The rapid expansion of human population on the planet over the past several hundred years is affecting habitats all over the globe. Many species have been or are being threatened by these impacts, so that some authors argue that we are facing a species extinction event of a magnitude that may rival the past five major extinction events through geologic time (Pievani 2014). Many factors are involved; however, two important factors include changes to climate (global climate change) and changes to the nitrogen $(\mathrm{N})$ cycle. Global climate change includes changes in temperature, which in many areas of the planet is predicted to increase (Warren et al. 2011; Stocker et al. 2013). Nitrogen is an important nutrient that limits primary productivity in many natural (as well as agricultural) systems; however, planet-wide $\mathrm{N}$ fixation by humans has recently been estimated to exceed that of all natural sources on Earth (Galloway et al. 1995; Fowler et al. 2013).

How plant species in special edaphic situations (including serpentine soils) will be affected by human-caused changes is not known and is under active investigation (Harrison et al. 2009; Fernandez-Going 2014). As summarised by Damschen et al. (2012), climate change, including changes in temperature and precipitation, may have relatively pronounced effects on serpentine-endemic plant species. Effects of $\mathrm{N}$ deposition on serpentine species are less investigated, but Vallano et al. (2012) concluded that $\mathrm{N}$ deposition on a California serpentine grassland increased the vulnerability of the habitat to invasion by exotic species. Kazakou et al. (2008) pointed out that many factors may limit plant growth on serpentine soils, including low $\mathrm{N}$ concentrations. Although the situation on Iranian serpentine soils has not been investigated, some studies in temperate-zone serpentine areas (such as California, USA) have reported that N limitation (e.g. O'Dell and Claassen 2006) may be an important factor.

The present study explored the effects of $\mathrm{Ca}: \mathrm{Mg}$ ratio, along with heat and $\mathrm{N}$ (in the form of ammonium) stress, on two Alyssum species, one of which is a serpentine endemic and the other a species found on non-serpentine soils. Our goal was to compare the $\mathrm{Ca}: \mathrm{Mg}$ ratio responses of the two species and then to determine how $\mathrm{Ca}: \mathrm{Mg}$ ratio may affect the response of each species to $\mathrm{N}$ enrichment or temperature stress, two key imminent environmental stressors worldwide.

\section{Materials and methods}

\section{Study species}

Alyssum inflatum Nyárády (Brassicaceae) is a serpentineendemic plant from western Iran, belonging to section Odontarrhena (Ghasemi and Ghaderian 2009; Ghasemi et al. $2009 a, 2009 b$ ). As a perennial, it is a fitting plant for long-term experiments and to examine survival and flowering under controlled conditions (Ghasemi et al. 2014). Seeds of A. inflatum were harvested from plants growing on serpentine soils of western Iran ( $\left.3513.625^{\prime} \mathrm{N}, 4627.184^{\prime} \mathrm{E}\right)$ in September 2009 and stored at $4 \mathrm{C}$ for at least 3 months to break dormancy.
Approximately 50000 seeds were collected as a bulk sample from $\sim 70$ plants and mixed thoroughly.

The non-serpentine congener, A. lanceolatum Baumgartner, was used as a comparative species. It is also a perennial, but is classified in section Alyssum (Hedge and Rechinger 1968). Seeds of A. lanceolatum were harvested from plants growing on non-serpentine soils of central Iran located in the Karkas Mountains $\left(3332.364^{\prime} \mathrm{N}, 5147.015^{\prime} \mathrm{E}\right)$. About 20000 seeds were collected from $\sim 100$ plants. All seeds were stored at $4 \mathrm{C}$ for at least 3 months to break dormancy.

\section{Field soil conditions}

Soil samples were collected from the two field sites to characterise their $\mathrm{Ca}: \mathrm{Mg}$ ratios. At each site, soil was collected down to 20-30-cm depth near the locations of plants; 12 samples were collected from the A. inflatum serpentine soil and three from the A. lanceolatum non-serpentine soil.

Sample preparation for measurement of total and extractable soil concentrations of elements was based on the method of Reeves et al. (1999). For measurement of total elements, soil samples of $4-5 \mathrm{~g}$ were ground to pass through an 80-mesh $(<190 \mu \mathrm{m})$ sieve and then oven-dried at $70 \mathrm{C}$. A further subsample of $0.5 \mathrm{~g}$ was transferred to a digestion tube for interaction with $10 \mathrm{~mL}$ of a $3: 1 \mathrm{HCl}-\mathrm{HNO}_{3}$ mixture. Tubes were left at room temperature overnight and were then placed in a heating block. Each tube was refluxed gently at $80 \mathrm{C}$ for $2 \mathrm{~h}$. After cooling, the digests were filtered through moistened Whatman No. \#40 filter paper into a $50-\mathrm{mL}$ volumetric flask. Flasks were then brought up to volume with distilled water. Measurement of $\mathrm{Ni}, \mathrm{Mg}$ and $\mathrm{Ca}$ concentrations was performed by atomic absorption spectrophotometry (AAS, Philips, model: PU9100X, The Netherlands).

To measure the concentrations of ammonium nitrateextractable soil elements, samples were prepared according to Gryschko et al. (2005). First, $20 \mathrm{~g}$ of air-dried ( $<2 \mathrm{~mm}$ sieved) soil was placed in a $100-\mathrm{mL}$ screw-cap polythene bottle, $50 \mathrm{~mL}$ of $1 \mathrm{M}$ $\mathrm{NH}_{4} \mathrm{NO}_{3}$ solution ( $\mathrm{pH} 6$ ) was then added, and the suspension was shaken for $2 \mathrm{~h}$ at $20 \mathrm{C}$ in an end-over-end shaker. After shaking, soil suspensions were left to stand for $5 \mathrm{~min}$ and then filtered (Whatman No. \#42 filter paper) into a clean bottle. Filtrates were then acidified with $0.2 \% \mathrm{HNO}_{3}$ for measurement of elements by AAS.

\section{General experimental procedures}

Experiments were performed by using solution culture infiltrated into the chemically inert substrate, perlite. Pots $(450 \mathrm{~mL})$ were filled with perlite and eight seeds were sown in each pot. After germination, seedlings were watered with modified Hoagland solution (pH 7), containing $1 \mathrm{mM} \mathrm{Ca}\left(\mathrm{NO}_{3}\right)_{2}, 0.1 \mathrm{mM} \mathrm{KH}_{2} \mathrm{PO}_{4}$, $0.5 \mathrm{mM} \mathrm{MgSO}_{4}, 0.5 \mathrm{mM} \mathrm{KNO}_{3}, 0.2 \mu \mathrm{M} \mathrm{CuSO}_{4}, 0.2 \mu \mathrm{M} \mathrm{ZnSO}_{4}$, $2 \mu \mathrm{M} \mathrm{MnSO}_{4}, 10 \mu \mathrm{M} \mathrm{H}_{3} \mathrm{BO}_{3}, 0.1 \mu \mathrm{M} \mathrm{Na}_{2} \mathrm{MoO}_{4}, 2 \mu \mathrm{M} \mathrm{NaCl}$ and $5 \mu \mathrm{M}$ ferric ethylenediamine-di-2-hydroxyphenylacetate (FeEDDHA). Pots were placed in three replicate trays (one pot per tray) and Hoagland solution was poured into the trays ( $400 \mathrm{~mL}$ per tray). Evaporation was compensated by daily addition of distilled water to the solutions to keep them at a constant volume. The solutions under the pots were replaced every 5 days. 
Experiments were performed in a semi-controlled glasshouse under natural light. Minimum and maximum temperatures were $23 \mathrm{C}$ and $36 \mathrm{C}$ in spring and summer, and $15 \mathrm{C}$ and $25 \mathrm{C}$ in late autumn and winter, respectively.

Survival of plants was determined by counting the number of live plants in each treatment category. Plants with wilted shoots were tested for living root cells by using Evan's blue stain (Mergemann and Sauter 2000). The roots were cut in lengths of $\sim 5 \mathrm{~cm}$ (measured from the root tip) and were submerged in a $2 \%$ stain solution for $2 \mathrm{~min}$. Stained roots were washed with the nutrient solution to prevent possible damage of cells via extreme change in osmotic pressure if distilled water was used. Staining of the root cells, which is a sign of high permeability and loss of function of plasma membrane and cell death, was checked using a brightfield microscope. Wilted plants whose roots took up stain were considered to be dead, and the date of death was recorded.

\section{Ca:Mg ratio experiment}

We used 1-month-old plants of both species for this experiment (24 plants per treatment: 3 pots 8 plants per pot). We added varying amounts of $\mathrm{Ca}$ nitrate to the nutrient solutions $(\mathrm{Ca}$ concentrations of $0.2,1,10$ and $20 \mathrm{mM}$ ) to yield a wide range of $\mathrm{Ca}: \mathrm{Mg}$ ratios $(0.4,2,20$ and 40, respectively). Effects of $\mathrm{Ca}: \mathrm{Mg}$ ratio on plants were determined at 25-day intervals for a period of 250 days ( $~ 8$ months), beginning in early June and ending in January of the following year. The date on which a plant showed visible stress symptoms (wilting and drying of leaves) was recorded and the Evan's blue stain technique was used to confirm date of death for each plant that died during the experiment.

\section{Ammonium stress experiment}

Two factors, ammonium and $\mathrm{Ca}: \mathrm{Mg}$ ratio, were manipulated in this experiment, using ammonium nitrate in concentrations of 0 , 1 and $4 \mathrm{mM}$, and Ca nitrate in concentrations of 1,5 and $10 \mathrm{mM}$ (producing $\mathrm{Ca}: \mathrm{Mg}$ ratios of 2, 10 and 20, respectively). These $\mathrm{Ca}: \mathrm{Mg}$ ratios were chosen to include the optimum ratio for survival of $A$. inflatum $(\mathrm{Ca}: \mathrm{Mg}=2$, as revealed by the $\mathrm{Ca}: \mathrm{Mg}$ ratio experiment; see Results below), as well as two much greater ratios. Three replicates of each treatment ( 24 plants per treatment: 3 pots 8 plants per pot) were used in a factorial complete block experimental design. This experiment was performed during autumn and winter (starting late September and finishing in early January), so that plants experienced relatively low average temperatures (compared with spring and summer).

\section{Heat-stress experiment}

The experiment examining the influence of $\mathrm{Ca}: \mathrm{Mg}$ ratio on survival when plants were heat stressed used two concentrations of $\mathrm{Ca}, 1 \mathrm{mM}$ and $10 \mathrm{mM}$, to produce solution $\mathrm{Ca}: \mathrm{Mg}$ ratios of 2 and 20, respectively. As with the ammoniumstress experiment, the $\mathrm{Ca}: \mathrm{Mg}$ ratios included the optimum for A. inflatum survival $(\mathrm{Ca}: \mathrm{Mg}=2)$ as well as a much higher ratio for comparison. Seeds were germinated in late September, using the basic medium, and 1-month-old plants (24 plants per treatment: 3 pots 8 plants per pot) were placed in either of the two $\mathrm{Ca}: \mathrm{Mg}$ ratio treatment conditions for 40 days. In late
November, plants were transferred to a growth cabinet with 16/8 h light/dark and $28 \mathrm{C} / 22 \mathrm{C}$ temperature cycle for 2 days, and the $\mathrm{Ca}: \mathrm{Mg}$ treatments were maintained for the duration of the experiment. After the 2-day acclimation period, during the following week, the temperature in the growth cabinet was raised to $36 \mathrm{C}$ for $5 \mathrm{~h}$ during the light photoperiod. At the end of the week-long daily heat treatment, plants were evaluated as alive or dead, on the basis of the Evan's blue stain test of the roots of wilted plants.

\section{Statistical analyses}

In the $\mathrm{Ca}: \mathrm{Mg}$ ratio experiment, $A$. lanceolatum plants grew well in all treatments and did not show signs of stress. Stress was observed only for $A$. inflatum plants. Therefore, we analysed data from $A$. inflatum to determine whether $\mathrm{Ca}: \mathrm{Mg}$ ratio significantly affected the time it took for stress to result in plant mortality. Survival among treatments was compared with survival analysis, using the Kaplan-Meier estimate and the Peto-Peto-Wilcoxon test in StatView 5.0 (SAS Institute 2005).

For the ammonium-stress experiment, effects of the $\mathrm{Ca}: \mathrm{Mg}$ ratio on plant survival were also analysed by survival analysis (SAS Institute 2005) for those ammonium treatments for which at least some plant mortality occurred. In those cases, we compared survival of plants to determine whether $\mathrm{Ca}: \mathrm{Mg}$ ratio affected results. If it did, we then compared results for specific $\mathrm{Ca}: \mathrm{Mg}$ treatments from the same ammonium treatment, using survival analysis in a pairwise fashion. We compared data from ratios of 2 and 10, as well as 10 and 20, to determine which result was contributing most to the overall significant $\mathrm{Ca}: \mathrm{Mg}$ ratio effect.

For the heat-stress experiment, survival of plants in each pot after the week-long period of daily heat treatments was calculated as a decimal fraction and the resulting values were arcsine squareroot transformed to ensure a more normal data distribution (Zar 1996). Transformed survival fractions were analysed using two-way ANOVA in StatView 5.0 (SAS Institute 2005), with $\mathrm{Ca}: \mathrm{Mg}$ ratio and Alyssum species as the two main factors, and including the interaction term.

\section{Results}

\section{Field soil conditions}

As expected, the serpentine soil had a low $\mathrm{Ca}: \mathrm{Mg}$ ratio and high concentrations of $\mathrm{Ni}$ compared with non-serpentine soil. Mean (s.e. in parentheses) $\mathrm{Ca}: \mathrm{Mg}$ ratios for the 12 soil samples collected from serpentine sites in western Iran were 0.041 (0.004) for total $\mathrm{Ca}: \mathrm{Mg}$ ratio and $1.6(0.17)$ for ammonium nitrateextractable $\mathrm{Ca}: \mathrm{Mg}$ ratio, with total $\mathrm{Ni}$ concentrations of 1600 (38) $\mathrm{mg} \mathrm{kg}^{-1}$, and ammonium extractable of $1.6(0.10) \mathrm{mg} \mathrm{kg}^{-1}$. The $\mathrm{Ca}: \mathrm{Mg}$ ratios for the three soil samples collected from the non-serpentine sites were 5.1 for the total $\mathrm{Ca}: \mathrm{Mg}$ ratio and 14.5 for ammonium nitrate-extractable $\mathrm{Ca}: \mathrm{Mg}$ ratio, with total $\mathrm{Ni}$ concentrations of $17 \mathrm{mg} \mathrm{kg}^{-1}$ (2.7) and ammonium extractable of $0.69 \mathrm{mg} \mathrm{kg}^{-1}(0.18)$.

\section{Ca:Mg ratio experiment}

The non-serpentine species, $A$. lanceolatum, did not show stress symptoms in any treatments and suffered no mortality (Fig. 1). In contrast, $\mathrm{Ca}: \mathrm{Mg}$ ratio significantly affected survival of the serpentine species, A. inflatum (Peto-Peto-Wilcoxon test, 


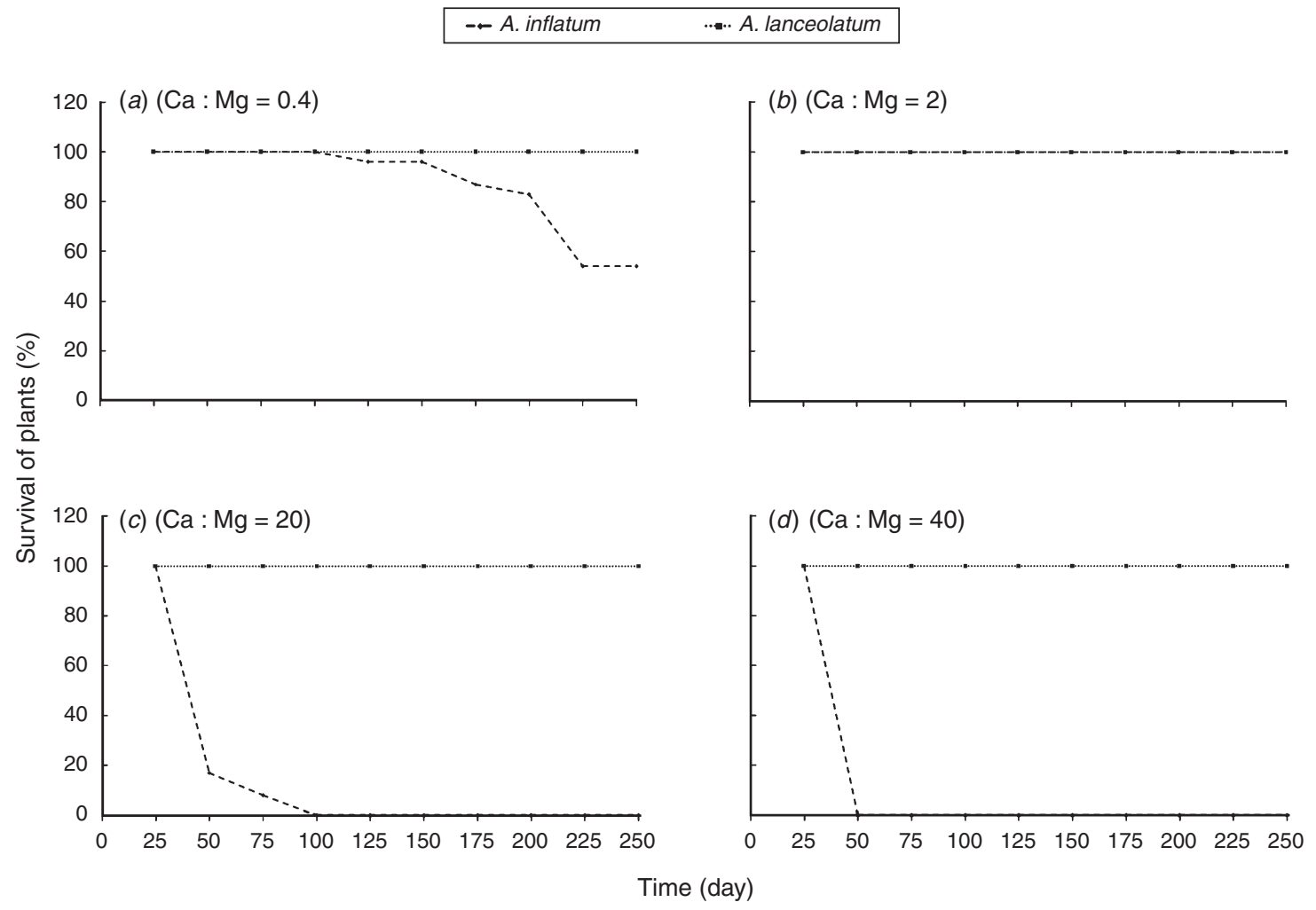

Fig. 1. Effect of varying calcium (Ca) : magnesium (Mg) ratio on survival of serpentine Alyssum inflatum and non-serpentine $A$. lanceolatum (a) $\mathrm{Ca}: \mathrm{Mg}=0.4$, (b) $\mathrm{Ca}: \mathrm{Mg}=2$, (c) $\mathrm{Ca}: \mathrm{Mg}=20$ and (d) $\mathrm{Ca}: \mathrm{Mg}=40$.

$\chi^{2}=109$, d.f. $=3, P<0.0001$; Fig. 1$)$. At 250 days, no plants from the $\mathrm{Ca}: \mathrm{Mg}=2$ treatment had died, whereas almost half $(46 \%)$ of plants from the $\mathrm{Ca}: \mathrm{Mg}=0.4$ treatment had died. Survival analysis showed that these responses were significantly different (Peto-Peto-Wilcoxon test, $\chi^{2}=11$, d.f. $=2, P=0.008$ ). High $\mathrm{Ca}: \mathrm{Mg}$ ratios resulted in much more rapid mortality; comparison of data from $\mathrm{Ca}: \mathrm{Mg}=2$ and $\mathrm{Ca}: \mathrm{Mg}=20$ showed a highly significant difference (Peto-Peto-Wilcoxon test, $\chi^{2}=53$, d.f. $\left.=1, P<0.0001\right)$. Data from the $\mathrm{Ca}: \mathrm{Mg}$ ratio $=40$ treatment showed the most rapid onset of stress symptoms; comparison with data from $\mathrm{Ca}: \mathrm{Mg}=20$ showed a significant difference (Peto-Peto-Wilcoxon test, $\chi^{2}=4.3, \quad$ d.f. $=1$, $P=0.039)$.

\section{Ammonium-stress experiment}

The two species responded to these treatments very differently. No mortality was observed for the non-serpentine A. lanceolatum under any treatment in the experiment. In contrast, the serpentine endemic $A$. inflatum experienced no or low mortality for all $\mathrm{Ca}: \mathrm{Mg}$ ratios under control (no ammonium) conditions, whereas mortality increased as $\mathrm{Ca}: \mathrm{Mg}$ ratio increased for both 1 and $4 \mathrm{mM}$ ammonium concentrations, with greatest mortality documented for plants in the highest $\mathrm{Ca}: \mathrm{Mg}$ ratio and ammonium concentrations (Fig. 2).

For $1 \mathrm{mM}$ ammonium, survival analysis indicated an overall $\mathrm{Ca}: \mathrm{Mg}$ ratio treatment effect (Peto-Peto-Wilcoxon test, $\chi^{2}=49$, d.f. $=2, P<0.0001)$, but there was no mortality at the lowest $\mathrm{Ca}: \mathrm{Mg}$ ratio and very little for the $\mathrm{Ca}: \mathrm{Mg}=10$ treatment; these results did not differ significantly (Peto-Peto-Wilcoxon test, $\chi^{2}=0.66, \quad$ d.f. $\left.=1, \quad P=0.415\right)$. However, at $\mathrm{Ca}: \mathrm{Mg}=20$, mortality was $19 \%$ by the end of the experiment and survival analysis showed that the survival curves of the $\mathrm{Ca}: \mathrm{Mg}=10$ and $\mathrm{Ca}: \mathrm{Mg}=20$ treatments differed significantly (Peto-PetoWilcoxon test, $\chi^{2}=21$, d.f. $\left.=2, P<0.0001\right)$.

At $4 \mathrm{mM}$ ammonium (Fig. 2), mortality was observed for only one plant in the entire experiment at $\mathrm{Ca}: \mathrm{Mg}=2$; however, mortality was much more severe as $\mathrm{Ca}: \mathrm{Mg}$ increased. Survival analysis showed a significant $\mathrm{Ca}: \mathrm{Mg}$ effect for the entire $4 \mathrm{mM}$ ammonium dataset (Peto-Peto-Wilcoxon test, $\chi^{2}=37$, d.f. $=2, P<0.0001)$, but again, comparison of data from the treatments with $\mathrm{Ca}: \mathrm{Mg}=2$ and $\mathrm{Ca}: \mathrm{Mg}=10$ showed no significant difference (Peto-Peto-Wilcoxon test, $\chi^{2}=1.5$, d.f. $=1, P=0.225)$. As with the $1 \mathrm{mM}$ ammonium treatment, low survival of plants in the $\mathrm{Ca}: \mathrm{Mg}=20$ treatment was driving the overall significant $\mathrm{Ca}: \mathrm{Mg}$ effect, as shown by the highly significant difference between survival of plants in $\mathrm{Ca}: \mathrm{Mg}=10$ and $\mathrm{Ca}: \mathrm{Mg}=20$ treatments (Peto-Peto-Wilcoxon test, $\chi^{2}=15$, d.f. $\left.=1, P=0.0001\right)$.

\section{Heat-stress experiment}

Two-way ANOVA showed significant effects of all factors, namely, $\mathrm{Ca}: \mathrm{Mg}$ ratio, species and the interaction $\left(F_{1,8}=20\right.$, $P=0.0021$, for each factor and the interaction). All plants of both species survived after the week-long heat-stress period in the $\mathrm{Ca}: \mathrm{Mg}$ ratio $=2$ treatment (Fig. 3), whereas, for the $\mathrm{Ca}: \mathrm{Mg}$ ratio $=20$ treatment, all non-serpentine plants (A. lanceolatum) 

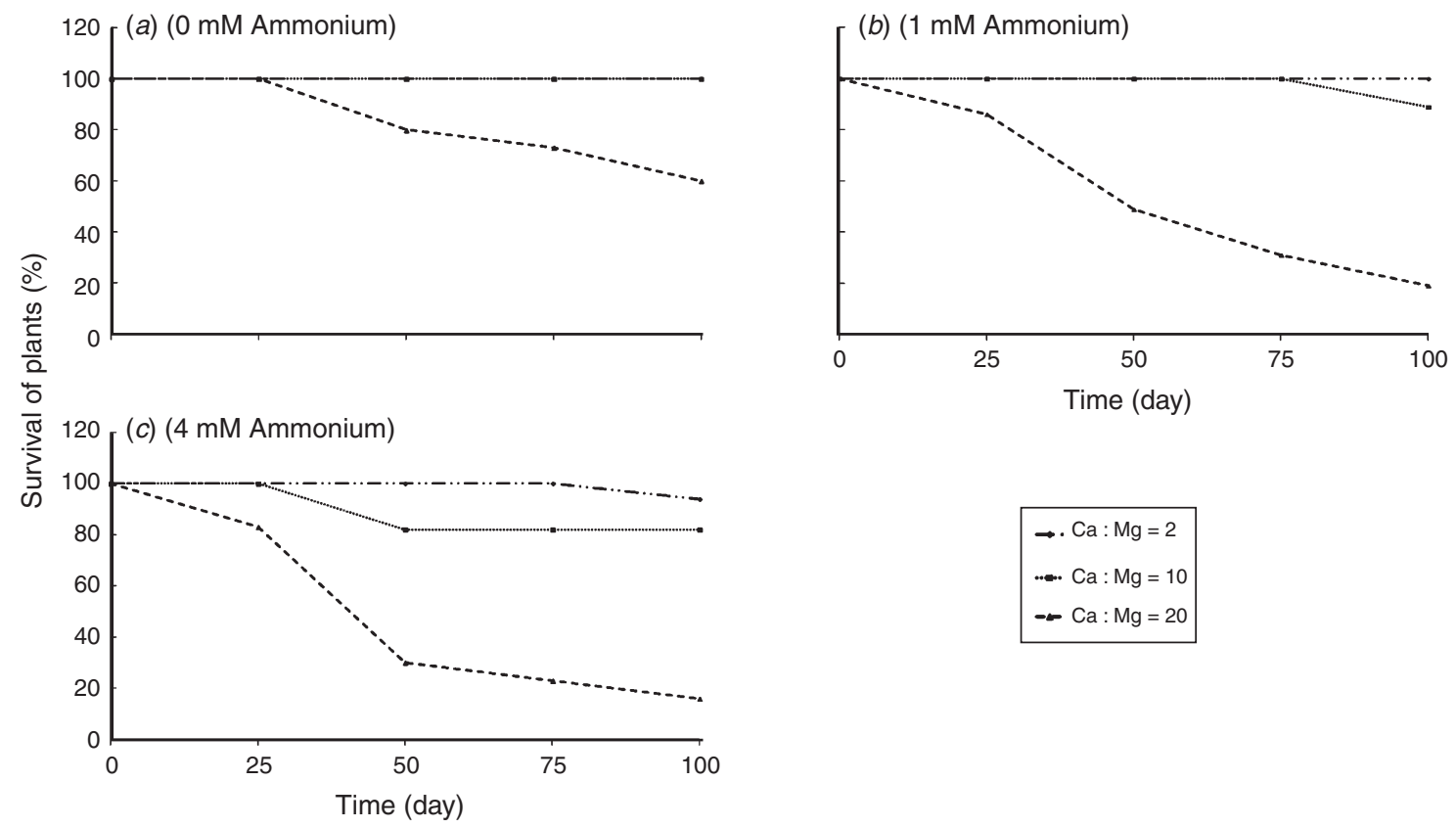

ig. 2. Effect of ammonium treatments on survival of serpentine Alyssum inflatum grown at three calcium $(\mathrm{Ca}): \mathrm{magnesium}(\mathrm{Mg})$ ratios $(\mathrm{Ca}: \mathrm{Mg}=2$, 10 and 20). (a) $0 \mathrm{mM}$ ammonium, (b) $1 \mathrm{mM}$ ammonium and, (c) $4 \mathrm{mM}$ ammonium.

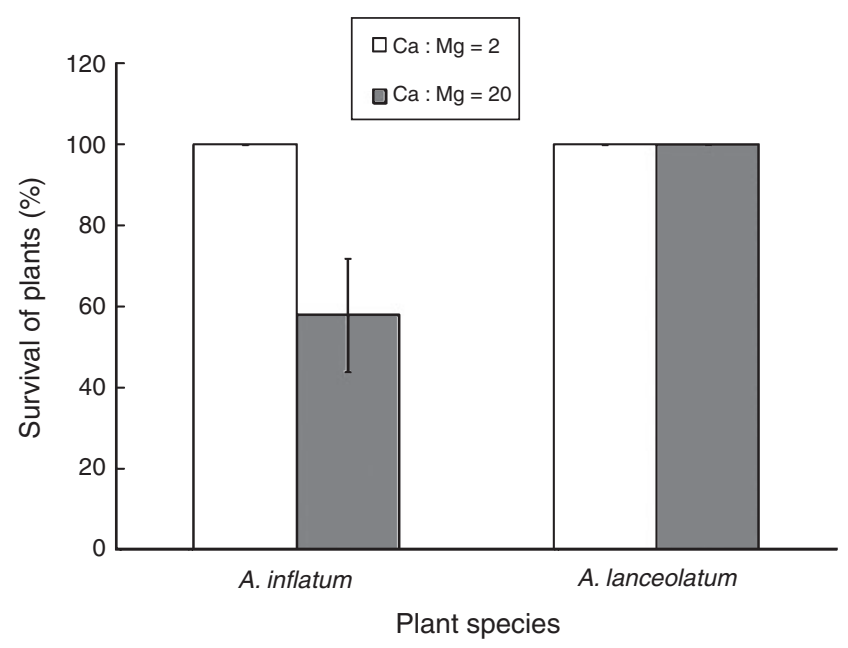

Fig. 3. Survival of serpentine Alyssum inflatum and non-serpentine A. lanceolatum after a week-long period of daily 5-h heat-stress treatments when grown at two calcium $(\mathrm{Ca})$ : magnesium $(\mathrm{Mg})$ ratios $(\mathrm{Ca}: \mathrm{Mg}=2$ and 20). Error bars represent s.e. (bar present only for $A$. inflatum at $\mathrm{Ca}: \mathrm{Mg}=20$, because survival was $100 \%$ for other bars).

survived, but only $63 \%$ of plants of the serpentine species (A. inflatum) survived (Fig. 3).

\section{Discussion}

Calcium and Mg are macronutrients (Epstein and Bloom 2004; Marschner 2011) and low $\mathrm{Ca}: \mathrm{Mg}$ ratios, especially those $<1$ characteristic of serpentine soils, represent a physiological stress to most plants (Brady et al. 2005); plants grow best when the $\mathrm{Ca}: \mathrm{Mg}$ of the soil is close to unity or greater (Lee 1998). A high proportion of plant $\mathrm{Ca}$ is located in the cell wall, bound to pectins in the middle lamella (White and Broadley 2003; Marschner 2011). Pectins play an important role in plant cell-wall stability and cell-to-cell adhesion (Jarvis 1984; Jarvis et al. 2003). Typical symptoms of $\mathrm{Ca}$ deficiency are cessation of cell-wall extension, disintegration of cell walls and tissue collapse (necrosis) as a result of pectin breakdown (Demarty et al. 1984; Jarvis 1984; Marschner 2011). These symptoms are often seen in actively growing tissues, such as root tips, new shoots and leaves. The exceedingly low $\mathrm{Ca}: \mathrm{Mg}$ ratios (often $<0.7$; Rajakaruna et al. 2009) typical of serpentine soils (and found in our analysis of the $A$. inflatum serpentine soil) require specialised physiological mechanisms to maintain adequate internal concentrations of $\mathrm{Ca}$. Such mechanisms include a greater acquisition of $\mathrm{Ca}$ (Wallace et al. 1982; Tibbetts and Smith 1993; Asemaneh et al. 2007) and the exclusion of Mg (Madhok and Walker 1969; Sambatti and Rice 2007). Some serpentine-adapted plants are indifferent to elevated Mg (Rajakaruna et al. 2003; Asemaneh et al. 2007), whereas others have a greater Mg requirement (Madhok 1965; Madhok and Walker 1969).

Whatever the strategy the plants use to deal with the low $\mathrm{Ca}: \mathrm{Mg}$ ratios typical of serpentine soils, our study showed that the serpentine-endemic species may have a narrow range of tolerance to soil $\mathrm{Ca}$ : $\mathrm{Mg}$ ratio. The endemic $A$. inflatum did best at $\mathrm{Ca}: \mathrm{Mg}=2$, a ratio close to the extractable $\mathrm{Ca}: \mathrm{Mg}$ ratio (1.67) of the serpentine soils from where the seeds were collected. Although it was clearly tolerant of the low (0.4) ratio, almost half $(46 \%)$ of plants from the $\mathrm{Ca}: \mathrm{Mg}=0.4$ treatment died within 7 months. It was also exceedingly sensitive to the high $\mathrm{Ca}: \mathrm{Mg}$ ratios in our experiment, showing high mortality after about 1 month from the start of the experiment. Interestingly, the non-serpentine species was broadly tolerant, showing no mortality under the entire range of $\mathrm{Ca}: \mathrm{Mg}$ ratios (including 0.4 , a ratio typical of serpentine soils). It is, therefore, surprising to 
not find $A$. lanceolatum on serpentine soils in Iran. Perhaps this is an indication of its lack of tolerance to other serpentine-related stressors, including heavy metals or drought.

Our study is the first effort exploring how plant performance under a range of $\mathrm{Ca}: \mathrm{Mg}$ ratios can be influenced by $\mathrm{N}$ deposition and temperature rise, two environmental stressors that threaten some habitats worldwide. Nitrogen deposition is a severe threat to those plants adapted to low-N habitats and has had drastic effects on native plant diversity not only on serpentine outcrops (Going et al. 2009; Vallano et al. 2012; Eskelinen and Harrison 2014) but also in arid deserts in California (Schneider and Allen 2012), limestone forests in the Alps (Hülber et al. 2008) and N-limited bogs in New England, USA (Gotelli and Ellison 2002), primarily by contributing to invasions by high N-loving exotic grasses. Our study showed that increased $\mathrm{N}$, in addition to encouraging the colonisation of high N-requiring invasive species, may also influence how serpentine-endemic species may respond to $\mathrm{Ca}: \mathrm{Mg}$ ratios. The serpentine-endemic species was increasingly sensitive to the high- $\mathrm{N}$ treatments under the high $\mathrm{Ca}: \mathrm{Mg}$ ratios, suggesting that under nutrient-rich conditions (i.e. high $\mathrm{N}$ and $\mathrm{Ca}$ ), serpentine-adapted plants can be outcompeted by those species able to thrive under such nutrient-enriched conditions. Calcium is known to stimulate the absorption of ammonium in plants (Fenn et al. 1995; Fenn and Feagley 1999); therefore, the increased $\mathrm{Ca}: \mathrm{Mg}$ ratio, under the higher ammonium concentrations, may have contributed to higher $\mathrm{N}$ in plant tissue, a feature that was beneficial to the non-serpentine species, but may have caused toxicity in the low $\mathrm{N}$-adapted serpentine endemic. It is possible that the higher mortality was also induced by greater ionic strength in the solution (in response to increases in $\mathrm{Ca}$ and ammonium), in addition to specific ion effects of $\mathrm{Ca}$ and ammonium. Therefore, future experiments should maintain the ionic strength (i.e. osmotic conditions) of the treatment solutions by altering the concentrations of $\mathrm{Ca}$ and $\mathrm{Mg}$, to confirm whether the increased mortality of the endemic taxon is in response to increased ammonium. However, it is interesting to note that the serpentine endemic was much more sensitive to the increases in $\mathrm{Ca}$ and ammonium than was the non-serpentine species.

Temperature increase, when combined with an increase in the $\mathrm{Ca}: \mathrm{Mg}$ ratio, also appeared to have a detrimental effect on the serpentine endemic compared with its non-serpentine congener. Calcium uptake is stimulated under high temperature (Klein and Ferguson 1987); therefore, it is possible that the exposure to high temperature led to an increase in Ca uptake under the higher $\mathrm{Ca}: \mathrm{Mg}$ ratios, a feature that was again beneficial to the nonserpentine taxon better adapted to deal with the higher $\mathrm{Ca}$ concentrations. Increased $\mathrm{Ca}$ uptake under higher temperature may have contributed to Ca toxicity in the serpentine endemic, leading to higher mortality under the high temperature and $\mathrm{Ca}: \mathrm{Mg}$ treatments. Increased $\mathrm{Ca}$ is also known to aid in heat tolerance (Gong et al. 1998; Jiang and Huang 2001); therefore, in the taxon adapted to higher $\mathrm{Ca}$, the increased $\mathrm{Ca}$ concentration may also have contributed to higher temperature tolerance. However, to confirm whether higher temperatures increase the Ca sensitivity of the serpentine-endemic species compared with its non-serpentine congener, both species should be grown at a constant high temperature (e.g. $25 \mathrm{C}$ ) and exposed to high $\mathrm{Ca}: \mathrm{Mg}$ ratios (e.g. 20 and 40) in future studies.
It is generally accepted that competition plays a key role in restricting slow-growing and stress-tolerant species to less-fertile (low $\mathrm{N}, \mathrm{P}$ ) and ionically imbalanced $(<1 \mathrm{Ca}: \mathrm{Mg}$ ratio) serpentine soils (Moore and Elmendorf 2011); however, the experimental evidence for the role of competition in such edaphic restrictions is mixed (Fernandez-Going and Harrison 2013). Recently, there has been much interest in examining how edaphic factors will interact with climatic factors (temperature and precipitation) in generating and maintaining patterns of edaphic endemism (Harrison et al. 2009; Fernandez-Going et al. 2013). Experimental evidence is limited (Anacker 2014), but is required to determine the mechanistic basis for how climate can influence edaphic restriction. Our study explored how a serpentine-adapted species and its non-serpentine congener respond under a range of $\mathrm{Ca}: \mathrm{Mg}$ ratios to differing $\mathrm{N}$ and temperature regimes. The results suggested that the serpentine endemic has an extremely narrow range of tolerance to both edaphic ( $\mathrm{Ca}: \mathrm{Mg}$ and $\mathrm{N}$ ) and climatic (temperature) variables tested, compared with its non-serpentine congener. Although the study was performed using artificial substrate (i.e. chemically amended perlite) and plants were not grown together to directly test for competition, our study suggested that in a warmer and N-rich future, the non-serpentine species could potentially outcompete the serpentine-endemic species, even on serpentine soils, and especially if it is tolerant of other serpentine-associated stressors (such as heavy metals). At the same time, the serpentine endemic will not be able to move into non-serpentine habitats because those soils are generally richer in nutrients and, as our study documents, it is maladapted to high-nutrient conditions, especially high concentrations of $\mathrm{Ca}$ and $\mathrm{N}$.

A conceptual model of climate-edaphic influences on the future of edaphic floras (Harrison et al. 2009) predicts that, in regions where climate becomes warmer and wetter, serpentine endemics will be outcompeted by soil generalists. In this scenario, endemics will be restricted to the 'harshest' serpentine soils and become less common; this is clearly possible in the case of the Alyssum congeners we studied. The non-serpentine taxon is clearly better equipped to compete in high-Ca and $-\mathrm{N}$ soils under warming conditions and could potentially move into serpentine habitats in the future, especially if the soils become higher in $\mathrm{N}$ (via atmospheric $\mathrm{N}$ deposition; Phoenix et al. 2012) under the warming climate. The model also predicts that in regions where climate becomes warmer and drier, serpentine endemics will be less adversely affected than their non-serpentine congeners because the endemics are generally more adapted to drier conditions often characteristic of serpentine soils. In such cases, it is possible that endemics will expand their ranges into non-serpentine soils, even outcompeting soil generalist species. However, this appears to be an unlikely scenario in our case, at least with respect to temperature, because the endemic was less fit under higher temperature and in soils with higher $\mathrm{Ca}$ concentrations. It is also unclear how our congeners will respond to varying levels of water stress, because we did not test their relative performance under varying moisture treatments. Therefore, future studies should take into account temperature, moisture and nutrient enrichment and grow both taxa directly on and off serpentine soils, testing their relative performance under varying climatic and edaphic conditions. Such a study would add to the very limited number of experimental studies exploring how 
climate change can influence patterns of serpentine endemism (Anacker 2014; Fernandez-Going 2014).

\section{Acknowledgements}

This research was funded by University of Payame Noor, Iran, and Robert Boyd acknowledges support from the Alabama Agricultural Experiment Station Project No. ALA021-1-09008. We thank two anonymous reviewers for providing critical feedback on this paper, including suggestions for additional studies to explore the impacts of climate-nutrient stresses on serpentine-restricted plants.

\section{References}

Alexander EB, Coleman RG, Keeler-Wolf T, Harrison S (2007) 'Serpentine geoecology of western North America.' (Oxford University Press: New York)

Anacker BL (2011) Phylogenetic patterns of endemism and diversity. In 'Serpentine: the evolution and ecology of a model system'. (Eds SP Harrison, N Rajakaruna) pp. 49-79. (University of California Press: Berkeley, CA)

Anacker BL (2014) The nature of serpentine endemism. American Journal of Botany 101, 219-224. doi:10.3732/ajb.1300349

Anacker BL, Whittall J, Goldberg E, Harrison SP (2011) Origins and consequences of serpentine endemism in the California flora. Evolution 65, 365-376. doi:10.1111/j.1558-5646.2010.01114.x

Asemaneh T, Ghaderian SM, Baker AJM (2007) Responses to Mg/Ca balance in an Iranian serpentine endemic plant, Cleome heratensis (Capparaceae), and a related non-serpentine species, C. foliolosa. Plant and Soil 293, 49-59. doi:10.1007/s11104-006-9147-7

Bradshaw HD, Jr (2005) Mutations in CAX1 produce phenotypes characteristic of plants tolerant to serpentine soils. New Phytologist 167, 81-88. doi:10.1111/j.1469-8137.2005.01408.x

Brady KU, Kruckeberg AR, Bradshaw HD (2005) Evolutionary ecology of plant adaptation to serpentine soils. Annual Review of Ecology Evolution and Systematics 36, 243-266.

doi:10.1146/annurev.ecolsys.35.021103.105730

Brooks RR (1987) 'Serpentine and its vegetation: a multidisciplinary approach.' (Dioscorides: Portland, OR)

Damschen EI, Harrison S, Ackerly DD, Fernandez-Going BM, Anacker BL (2012) Endemic plant communities on special soils: early victims or hardy survivors of climate change? Journal of Ecology 100, 1122-1130. doi:10.1111/j.1365-2745.2012.01986.x

Demarty M, Morvan C, Thellier M (1984) Calcium and the cell wall. Plant, Cell \& Environment 7, 441-448. doi:10.1111/j.1365-3040.1984.tb01434.x

Epstein E, Bloom AJ (2004) 'Mineral nutrition of plants: principles and perspectives.' 2nd edn. (Sinauer Associates: Sunderland, MA)

Eskelinen A, Harrison S (2014) Exotic plant invasions under enhanced rainfall are constrained by soil nutrients and competition. Ecology $\mathbf{9 5}$, 682-692. doi:10.1890/13-0288.1

Fenn LB, Feagley S (1999) Review of beneficial uses of calcium and ammonium salts for stimulating plant growth and metabolite translocation. Communications in Soil Science and Plant Analysis 30, 2627-2641. doi:10.1080/00103629909370401

Fenn LB, Hasanein B, Burks CM (1995) Calcium-ammonium effects on growth and yield of small grains. Agronomy Journal 87, 1041-1046. doi:10.2134/agronj1995.00021962008700060002x

Fernandez-Going BM (2014) Climate change and the future of edaphic floras. In 'Plant ecology and evolution in harsh environments'. (Eds N Rajakaruna, RS Boyd, TB Harris) pp. 297-311. (Nova Science Publishers: New York)

Fernandez-Going BM, Harrison S (2013) Effects of experimental water addition depend on grassland community characteristics. Plant Ecology 214, 777-786. doi:10.1007/s11258-013-0207-9
Fernandez-Going BM, Harrison SP, Anacker BL, Safford HD (2013) Climate interacts with soil to produce beta diversity in Californian plant communities. Ecology 94, 2007-2018. doi:10.1890/12-2011.1

Fowler D, Coyle M, Skiba U, Sutton MA, Cape JN, Reis S, Sheppard LJ, Jenkins A, Grizzetti B, Galloway JN, Vitousek P, Leach A, Bouwman AF, Butterbach-Bahl K, Dentener F, Stevenson D, Amann M, Voss M (2013) The global nitrogen cycle in the twenty-first century. Philosophical Transactions of the Royal Society of London. Series B, Biological Sciences 368, doi:10.1098/rstb.2013.0164

Galloway JN, Schlesinger WH, Levy H, II, Michaels A, Schnoor JL (1995) Nitrogen fixation: anthropogenic enhancement-environmental response. Global Biogeochemical Cycles 9, 235-252. doi:10.1029/95GB00158

Ghasemi R, Ghaderian SM (2009) Responses of two populations of an Iranian nickel-hyperaccumulating serpentine plant, Alyssum inflatum Nyar., to substrate $\mathrm{Ca} / \mathrm{Mg}$ quotient and nickel. Environmental and Experimental Botany 67, 260-268. doi:10.1016/j.envexpbot.2009.06.016

Ghasemi R, Ghaderian SM, Krämer U (2009a) Accumulation of nickel in trichomes of a nickel hyperaccumulator plant, Alyssum inflatum. Northeastern Naturalist 16, 81-92. doi:10.1656/045.016.0507

Ghasemi R, Ghaderian SM, Krämer U (2009b) Interference of nickel with copper and iron homeostasis contributes to metal toxicity symptoms in the nickel hyperaccumulator plant Alyssum inflatum. New Phytologist 184, 566-580. doi:10.1111/j.1469-8137.2009.02993.x

Ghasemi R, Chavoshi ZZ, Boyd RS, Rajakaruna N (2014) A preliminary study of the role of nickel in enhancing flowering of the nickel hyperaccumulating plant Alyssum inflatum Nyár. (Brassicaceae). South African Journal of Botany 92, 47-52. doi:10.1016/j.sajb.2014.01.015

Going BM, Hillerislambers J, Levine JM (2009) Abiotic and biotic resistance to grass invasion in serpentine annual plant communities. Oecologia 159, 839-847. doi:10.1007/s00442-008-1264-y

Gong M, van der Luit AH, Knight MR, Trewavas AJ (1998) Heat-shockinduced changes in intracellular $\mathrm{Ca}^{2+}$ level in tobacco seedlings in relation to thermotolerance. Plant Physiology 116, 429-437. doi:10.1104/pp.116.1.429

Gotelli NJ, Ellison EM (2002) Nitrogen deposition and extinction risk in northern pitcher plant, Sarracenia purpurea. Ecology 83, 2758-2765. doi:10.1890/0012-9658(2002)083[2758:NDAERI]2.0.CO;2

Gryschko R, Kuhnle R, Terytze K, Breuer J, Stahr K (2005) Soil extraction of readily soluble heavy metals and As with $1 \mathrm{M} \mathrm{NH}_{4} \mathrm{NO}_{3}$-solution. Journal of Soils and Sediments 5, 101-106. doi:10.1065/jss2004.10.119

Harrison SP, Rajakaruna N (Eds) (2011) 'Serpentine: the evolution and ecology of a model system.' (University of California Press: Berkeley, CA)

Harrison SP, Damschen E, Going BM (2009) Climate gradients, climate change, and special edaphic floras. Northeastern Naturalist 16, 121-130.

Hedge I, Rechinger KH (1968) Cruciferae. In 'Flora Iranica'. (Ed. KH Rechinger) pp. 1-372. (Akademische Druck-u., Verlagsanstalt: Graz, Austria)

Hülber K, Dirnböck T, Kleinbauer I, Willner W, Dullinger S, Karrer G, Mirtl M (2008) Long-term impacts of nitrogen and sulphur deposition on forest floor vegetation in the northern limestone Alps, Austria. Applied Vegetation Science 11, 395-404. doi:10.3170/2008-7-18489

Jarvis MC (1984) Structure and properties of pectin gels in plant cell walls. Plant, Cell \& Environment 7, 153-164.

Jarvis MC, Briggs SPH, Knox JP (2003) Intercellular adhesion and cell separation in plants. Plant, Cell \& Environment 7, 153-164.

Jiang Y, Huang B (2001) Effects of calcium on antioxidant activities and water relations associated with heat tolerance in two cool-season grasses. Journal of Experimental Botany 52, 341-349. doi:10.1093/jexbot/52.355.341

Kay KM, Ward KL, Watt LR, Schemske DW (2011) Plant speciation. In 'Serpentine: the evolution and ecology of a model system'. (Eds SH Harrison, N Rajakaruna) pp. 181-199. (University of California Press: Berkeley, CA) 
Kazakou E, Dimitrakopoulos PG, Baker AJM, Reeves RD, Troumbis AY (2008) Hypotheses, mechanisms and trade-offs of tolerance and adaptation to serpentine soils: From species to ecosystem level. Biological Reviews of the Cambridge Philosophical Society 83, 495-508.

Klein JD, Ferguson IB (1987) Effect of high temperature on calcium uptake by suspension-cultured pear fruit cells. Plant Physiology 84, 153-156. doi: $10.1104 / p p .84 .1 .153$

Kruckeberg AR (1984) 'California serpentines: flora, vegetation, geology, soils, and management problems.' (University of California Press: Berkeley, CA)

Lee JA (1998) The calcicole-calcifuge problem revisited. Advances in Botanical Research 29, 1-30. doi:10.1016/S0065-2296(08)60306-7

Madhok OP (1965) Magnesium nutrition of Helianthus annuus L. and Helianthus bolanderi Gray subspecies exilis Heiser. PhD Dissertation. University of Washington, Seattle, WA.

Madhok OP, Walker RB (1969) Magnesium nutrition of two species of sunflower. Plant Physiology 44, 1016-1022. doi:10.1104/pp.44.7.1016

Marschner H (2011) 'Mineral nutrition of plants.' 3rd edn. (Academic Press: San Diego, CA)

Mergemann H, Sauter M (2000) Ethylene induces epidermal cell death at the site of adventitious root emergence in rice. Plant Physiology 124, 609-614. doi:10.1104/pp.124.2.609

Moore KA, Elmendorf SC (2011) Plant competition and facilitation in systems with strong environmental gradients. In 'Serpentine: the evolution and ecology of a model system'. (Eds SP Harrison, N Rajakaruna) pp. 223-236. (University of California Press: Berkeley, CA)

Myers N, Mittermeier RA, Mittermeier CG, da Fonseca GAB, Kent J (2000) Biodiversity hotspots for conservation priorities. Nature 403, 853-858. doi: $10.1038 / 35002501$

O'Dell RE, Claassen VP (2006) Serpentine and nonserpentine Achillea millefolium accessions differ in serpentine substrate tolerance and response to organic and inorganic amendments. Plant and Soil 279, 253-269. doi:10.1007/s11104-005-2360-y

O’Dell RE, Rajakaruna N (2011) Intraspecific variation, adaptation, and evolution. In 'Serpentine: the evolution and ecology of a model system'. (Eds SP Harrison, N Rajakaruna) pp. 97-137. (University of California Press: Berkeley, CA)

Palm ER, Van Volkenburgh E (2014) Physiological adaptations of plants to serpentine soils. In 'Plant ecology and evolution in harsh environments'. (Eds N Rajakaruna, RS Boyd, TB Harris) pp. 129-147. (Nova Science Publishers Inc.: New York)

Palm ER, Brady K, Van Volkenburgh E (2012) Serpentine tolerance in Mimulus guttatus does not rely on exclusion of magnesium. Functional Plant Biology 39, 679-688. doi:10.1071/FP12059

Phoenix GK, Emmet BA, Britton AJ, Caporn SJM, Dise NB, Helliwell R, Jones L, Leake JR, Leith ID, Sheppard LJ, Sowerby A, Pilkington MG, Rowe EC, Ashmore MR, Power SA (2012) Impacts of atmospheric nitrogen deposition: responses of multiple plant and soil parameters across contrasting ecosystems in long-term field experiments. Global Change Biology 18, 1197-1215. doi:10.1111/j.1365-2486.2011.02590.x

Pievani T (2014) The sixth mass extinction: anthropocene and the human impact on biodiversity. Rendiconti Lincei 25, 85-93.

doi: $10.1007 / \mathrm{s} 12210-013-0258-9$
Rajakaruna N, Boyd RS (2008) The edaphic factor. In 'Encyclopedia of ecology. Vol. 2'. (Eds SE Jorgensen, B Fath) pp. 1201-1207. (Elsevier: Oxford, UK)

Rajakaruna N, Siddiqi MY, Whitton J, Bohm BA, Glass ADM (2003) Differential responses to $\mathrm{Na}^{+} / \mathrm{K}^{+}$and $\mathrm{Ca}^{2+} / \mathrm{Mg}^{2+}$ in two edaphic races of the Lasthenia californica (Asteraceae) complex: a case for parallel evolution of physiological traits. New Phytologist 157, 93-103. doi:10.1046/j.1469-8137.2003.00648.x

Rajakaruna N, Harris TB, Alexander EB (2009) Serpentine geoecology of eastern North America: a review. Rhodora 111, 21-108. doi:10.3119/07-23.1

Reeves RD, Baker AJM, Borhidi A, Berazaín R (1999) Nickel hyperaccumulation in the serpentine flora of Cuba. Annals of Botany 83, 29-38. doi:10.1006/anbo.1998.0786

Safford HD, Viers JH, Harrison SP (2005) Serpentine endemism in the California flora: a database of serpentine affinity. Madrono 52, 222-257. doi:10.3120/0024-9637(2005)52[222:SEITCF]2.0.CO;2

Sambatti JBM, Rice KJ (2007) Functional ecology of ecotypic differentiation in the Californian serpentine sunflower (Helianthus exilis). New Phytologist 175, 107-119. doi:10.1111/j.1469-8137.2007.02068.x

SAS Institute (2005) 'StatView 5.0.' (Thomson-Brooks/Cole: Belmont, CA)

Schneider HE, Allen EB (2012) Effects of elevated nitrogen and exotic plant invasion on soil seed bank composition in Joshua Tree National Park. Plant Ecology 213, 1277-1287. doi:10.1007/s11258-012-0085-6

Stocker TF, Qin D, Plattner GK, Tignor M, Allen SK, Boschung J, Nauels A, Xia Y, Bex V, Midgley PM (2013) 'Climate change 2013: the physical basis. Contribution of the Working Group I to the fifth assessment report of the Intergovernmental Panel on Climate Change.' (Cambridge University Press: New York)

Tibbetts RA, Smith JAC (1993) Vacuolar accumulation of calcium and its interaction with magnesium availability. In 'The vegetation of ultramafic (serpentine) soils: proceedings of the first international conference on serpentine ecology'. (Eds AJM Baker, J Proctor, RD Reeves) pp. 367-373. (Intercept: Andover, UK)

Vallano DM, Selmants PC, Zavaleta ES (2012) Simulated nitrogen deposition enhances performance of an exotic grass relative to native serpentine grassland competitors. Plant Ecology 213, 1015-1026. doi:10.1007/s11258-012-0061-1

Van der Ent A, Repin R, Sugau J, Wong KM (2014) 'The ultramafic flora of Sabah: an introduction to the plant diversity on ultramafic soils.' (Natural History Publications (Borneo): Kota Kinabalu, Borneo)

Wallace A, Jones MB, Alexander GV (1982) Mineral composition of native woody plants growing on serpentine soil in California. Soil Science 134, 42-44. doi:10.1097/00010694-198207000-00008

Warren R, Price J, Fischlin A, de la Nava Santos S, Midgley G (2011) Increasing impacts of climate change upon ecosystems with increasing global mean temperature rise. Climatic Change 106, 141-177. doi:10.1007/s10584-010-9923-5

White PJ, Broadley MR (2003) Calcium in plants. Annals of Botany 92, 487-511. doi:10.1093/aob/mcg164

Zar JH (1996) 'Biostatistical analysis.' (Prentice-Hall: Englewood Cliffs, NJ) 